\author{
ROMAN KISIEL \\ ORCID https://orcid.org/0000-0002-3282-1378 \\ WIESŁAWA LIZIŃSKA \\ ORCID https://orcid.org/0000-0002-6957-2846 \\ PAULINA Rosochacka \\ Uniwersytet Warmińsko-Mazurski w Olsztynie
}

\title{
MIGRACJE ZAROBKOWE POLAKÓW W KONTEKŚCIE BREXITU
}

\section{Gainful Migrations of Poles in the Context of Brexit}

\begin{abstract}
WYRAZY KLUCZOWE: migracja, migracja zarobkowa, brexit, Unia Europejska, Wielka Brytania
KEYWORDS: migration, gainful migration, Brexit, European Union, Great Britain

Aвstract: The purpose of the work was to diagnose the scale of the phenomenon of labor migration of Poles to Great Britain. Data on population flows were used (emigration, immigration and migration balance) in 2004-2014. An attempt was also made to diagnose migration changes caused by the Brexit referendum. For this purpose, data were used in the years 2014-2016. The secondary data from Eurostat, the Macroeconomic Data Bank and Demographic Year 2017 (CSO) were used to analyze and assess the phenomenon of migration in the analyzed periods. The majority of migrant workers came to the British Isles in 2006. In the following years, interest in going abroad for long-term was not so great. There were definitely more Polish residents who decided to go for a short-term than for long-term. Another such a big interest in going for longterm to Great Britain took place in 2013. This tendency did not last too long. The referendum did not have a big impact on the short-term migra-tion. However, it reduced the willingness to go away for long-term.
\end{abstract}

\section{Wstęp}

Zjawisko migracji swoje początki bierze od czasów, kiedy zaczęły tworzyć się większe skupiska ludności związane z określonym obszarem. W związku z tym można powiedzieć, że migracje są integralną częścią dziejów ludzkości (Kaczmarczyk 2015). Ludzie przemieszczają się z każdego państwa na świecie, a źródłem nasilania się tego zjawiska jest ewidentna poprawa warunków w zakresie mobilności ludności (Woźniak 1999). 
Migracja jest złożonym zjawiskiem, które wymaga szczegółowej analizy i rozpatrywania go w szerokim kontekście. Zjawisko to niezaprzeczalnie problem demograficzny, socjologiczny, politologiczny, ekologiczny, kulturoznawczy i ekonomiczny, lecz na podstawie tych nauk nie jest możliwe jego pełne wyjaśnienie i zrozumienie (Kuciński 2004).

Migracje zagraniczne determinuje wiele czynników. Chodzi nie tylko o samo ich występowanie i oddziaływanie, ale często o postrzeganie ich jako sił motywujących potencjalnych migrantów do zmiany kraju zamieszkania i pracy. Są to czynniki typu ekonomicznego, jak i pozaekonomicznego. Charakter ekonomiczny czynników wynika przede wszystkim z nierównomiernego wyposażenia krajów w zasoby siły roboczej. To z kolei przyczynia się do międzynarodowego zróżnicowania stawek płac, możliwości zatrudnienia itp. Jednym z istotnych czynników ekonomicznych mających wpływ na rozwój migracji zagranicznych jest również kształtowanie się koniunktury gospodarczej, co wpływa na rozmiary popytu na pracę (Siek/Bednarczyk 2009, 163-164).

Zmiana miejsca zamieszkania bądź pobytu na jakiś czas za granicą powoduje różne konsekwencje, które dotyczą zarówno kraju pochodzenia migrantów, jak i kraju ich przyjmującego. Skutki te mogą mieć różny charakter i wywierać wpływ na sferę gospodarczą, a także społeczną. Zasięg i skala tego procesu spowodowała, że migracje stały się jednym z najistotniejszych międzynarodowych problemów współczesnego świata (Piklikiewicz 2000).

Ruch migracyjny ma duże znaczenie w Unii Europejskiej. To właśnie on kształtuje obecny bilans demograficzny w większości krajów tej organizacji gospodarczej, a tym samym wpływa na wzrost lub spadek liczby ludności oraz stosunek liczby osób w wieku produkcyjnym do liczby osób w wieku poprodukcyjnym. [...] Migracje zagraniczne mogą pomóc krajom Unii Europejskiej w walce z problemami demograficznymi wynikającymi ze starzenia się społeczeństwa. [...] Poza tym migracje zagraniczne wpływają na wzrost lub spadek bezrobocia, kształtowanie wizerunku oraz polityki zagranicznej poszczególnych krajów, a także wzrost lub spadek zainteresowania danymi obszarami przez inwestorów zagranicznych (Nowotnik 2011, 60).

W 2004 r., kiedy Polska wstąpiła do UE, a wiele państw zniosło barierę dotyczącą swobodnego przepływu ludności, emigracja Polaków o charakterze ekonomicznym do Wielkiej Brytanii miała masowy charakter. Dla Polaków powodem wyboru Wielkiej Brytanii na cel emigracji były względy ekonomiczne. Kraj ten w tym czasie prowadził aktywną politykę imigracyjną, sytuacja na rynku pracy była korzystna, a gospodarka należała do najpotężniejszych w Europie (Byczek 2014 ). W tym samym roku stwierdzono, że brytyjska gospodarka odczuwa niedobór ok. 600 tys. pracowników. Decydując się na złagodzenie przepisów w zakresie polityki migracyjnej, władze sądziły, że napływ ludności będzie kształtował się w granicach 25-30 tys. rocznie (Grabowska-Lucińska/Okólski 2009). „Jednak okazało się, że napływ był 
kilkanaście razy większy niż prognozowano już w pierwszym roku. W $2004 \mathrm{r}$. do Wielkiej Brytanii przybyło 439 tys. imigrantów" (Fihel 2007, 4).

Przez ostatnie kilkanaście lat najchętniej wybieranym przez Polaków krajem emigracji była Wielka Brytania. W wyniku napływu zbyt dużej liczby ludności państwo to zaczęło borykać się z problemami. Władze Wielkiej Brytanii, chcąc rozwiązać tę kwestię, 23 czerwca 2016 r. zorganizowały referendum w sprawie pozostania w Unii Europejskiej lub ewentualnego jej opuszczenia. Wynik głosowania był jednoznaczny - mieszkańcy zdecydowali w większości, że nie chcą być w UE. Data referendum stała się początkiem brexitu, natomiast zgodnie z traktatem lizbońskim Wielka Brytania powinna opuścić UE w ciągu 2 lat od rozpoczęcia procedury ${ }^{1}$.

Brexit zapoczątkował wiele zmian nie tylko w Wielkiej Brytanii, lecz także w całej Europie. Jest to zjawisko, które nie wystąpiło do tej pory w żadnym kraju UE. To Wielka Brytania jako pierwsza zdecydowała się na tak odważny krok i podjęła decyzję o opuszczeniu UE. W ostatnim czasie słowo to było na ustach niemal każdego Europejczyka. Terminologia tego rzeczownika pochodzi od połączenia początkowego członu br- od słowa Britain i słowa exit, czyli „wyjście”. Brexit to określenie używane potocznie, natomiast dokładnie oznacza proces, w którym Wielka Brytania opuszcza UE (Tomaszewski 2015).

[...] Kluczowym argumentem na rzecz Brexitu stało się przekonanie o negatywnym wpływie masowej imigracji z innych państw UE na rynek pracy Wielkiej Brytanii. Emigranci stworzyli bowiem dodatkową konkurencję na rynku pracy, zwłaszcza dla Anglików legitymujących się najniższymi kwalifikacjami (Kundera 2017, 59).

Brexit to proces, który jednoznacznie wiąże się ze zniesieniem swobody przepływu ludności, czyli ograniczeniem imigracji zarobkowej. Jego skutki będą odczuwać zarówno imigranci mieszkający w Wielkiej Brytanii, jak i mieszkańcy tego kraju. Opuszczenie przez Wielką Brytanię struktur UE spowoduje wiele zmian w brytyjskiej gospodarce i na rynku pracy. Brak pracowników sprawi, że wzrosną płace, czyli wzrośnie koszt zatrudnienia, a to z kolei wpłynie na spadek konkurencyjności gospodarki tego państwa (Borońska-Hryniewiecka 2016).

Celem niniejszego artykułu jest ukazanie skali zjawiska migracji zarobkowych Polaków do Wielkiej Brytanii, dlatego wykorzystano dane dotyczące przepływu ludności (emigracja, imigracja oraz saldo migracji) w latach 2004-2014. Jest to okres, w którym zaszło wiele istotnych zmian w migracji Polaków. Oprócz tego próbowano ustalić, czy i jakie zmiany spowodowało referendum w sprawie brexitu w migracji ludności na Wyspy Brytyjskie. W tym celu wykorzystano dane dotyczące migracji w latach 2014-2016. Do analizy i oceny zjawiska migracji w badanych okresach posłużono się danymi wtórnymi z Eurostatu, Banku Danych Makroekonomicznych oraz Rocznika demograficznego 2017, które pochodzą z Głównego Urzędu Statystycznego.

\footnotetext{
${ }^{1}$ http://www.lexlege.pl/traktat-o-unii-europejskiej/art-50/ [dostęp 20.08.2018].
} 


\section{Migracja do Wielkiej Brytanii w latach 2004-2014}

Wejście Polski do UE w maju 2004 r. miało wielki wpływ na skalę, charakter i kierunek emigracji Polaków. Zmiany, jakie zaszły na europejskim rynku pracy, które wynikały bezpośrednio z rozszerzenia członkostwa unijnego, spowodowały, że sposobność podjęcia pracy w każdym z krajów Unii decydowała o wyraźnej skłonności do zmiany miejsca zamieszkania przez ludność nowo przyjętych krajów członkowskich. W tym czasie większość państw starej UE, obawiając się napływu imigrantów, hamowała dostęp do własnych rynków pracy. Wyjątkiem były Wielka Brytania, Irlandia i Szwecja, które otworzyły swój rynek pracy dla mieszkańców nowo przyjętych państw (Podgórzańska 2016).

Polacy bardzo chętnie korzystali z możliwości wyjazdu za granicę, dla wielu z nich wyjazd był najlepszą alternatywą. Największa fala emigracji Polaków nastąpiła w 2006 r., gdy do Wielkiej Brytanii przyjechało na stałe 17,9 tys. Polaków, tj. o 14,9 tys. więcej niż rok wcześniej (rysunek 1). W tym czasie z Wysp na stałe do swojej ojczyzny wróciło tylko 1,5 tys. osób. Do 2008 r. więcej Polaków przyjeżdżało niż wyjeżdżało na stałe do Wielkiej Brytanii, natomiast od 2009 r. sytuacja się odwróciła. W 2009 r. 5,4 tys. imigrantów opuściło Wyspy, a przyjechała prawie połowa mniej obywateli Polski ( 3,5 tys.), co mogło być pośrednią przyczyną obecnego w tym czasie kryzysu finansowego w Europie. Od 2011 r. znów wzrosło zainteresowanie wyjazdem do Wielkiej Brytanii, jednak - jak pokazuje saldo migracji - przyjechało tylko o 56 osób więcej niż wyjechało. Według statystyk GUS

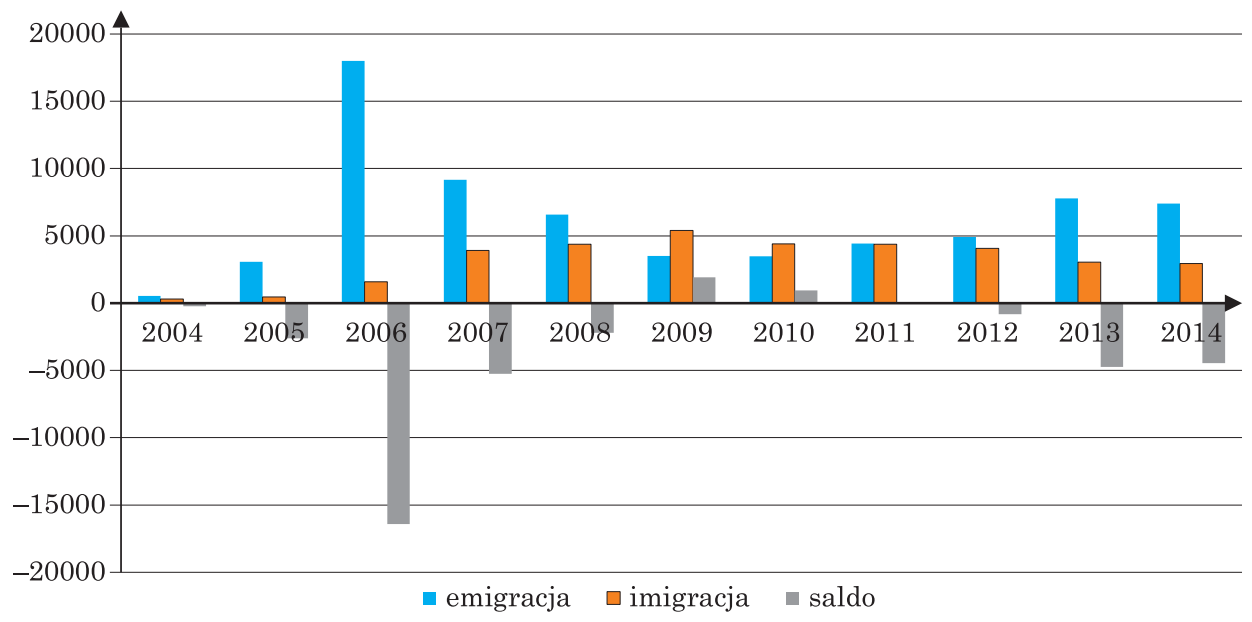

Rys. 1. Emigracja Polaków do Wielkiej Brytanii i imigracja Polaków z Wielkiej Brytanii oraz saldo w latach 2004-2014 (migracja na pobyt stały)

Źródło: opracowanie własne na podstawie GUS, Zestawienie: Główne kierunki emigracji i imigracji w latach 1966-2014 (migracje na pobyt stały), Warszawa, 20.08.2015 
w 2014 r. osiedliło się na stałe w Wielkiej Brytanii 7,3 tys. osób, a wyemigrowało na stałe 2,9 tys. osób, tj. najmniej od $2006 \mathrm{r}$.

Powyższa analiza danych potwierdza tylko, jak wielu Polaków zdecydowało się zostać na stałe w Wielkiej Brytanii. Dogodne warunki życia, jakie zastali na miejscu, utwierdziły ich tylko w tym, że podjęli słuszną decyzję. Dla polskiej gospodarki to jednak była wielka strata, gdyż wyjechali młodzi i bardzo dobrze wykształceni ludzie, których oczekiwania nie zostały spełnione w kraju.

Od kilkudziesięciu lat w Wielkiej Brytanii dostrzega się wysokie saldo migracji. W związku z wieloma zmianami w polityce migracyjnej oraz wzbogacaniu się UE o kolejne kraje napływ ludności stał się coraz większy, a Wielka Brytania zyskała największą popularność. $Z$ danych Eurostatu wynika, że Wielka Brytania jest drugim krajem, który przyjął najwięcej imigrantów w 2015 r. (631,5 tys.). Trzecie miejsce natomiast zajmuje w przypadku emigrantów (299,2 tys.) (według danych EUROSTAT z 2017 r.). Ze względu na nasilający się problem związany z imigracją zaczęto proponować zmiany w polityce migracyjnej tego kraju.

Warto podkreślić, że skala imigracji Polaków do Wielkiej Brytanii, jaka miała miejsce po 2004 roku, dla rządu brytyjskiego była zaskoczeniem. Szacowano, że przybędzie około 13 tys. pracowników z krajów UE - osiem w skali rocznej. Brytyjski system nie uwzględnia oczywiście osób, które pracują nielegalnie. Poza tym system ten rejestruje tylko wejście na brytyjski rynek, bez skreślania osób, które już go opuściły. Statystyki te pokazują jednak, że Polacy w Wielkiej Brytanii stanowią najliczniejszą grupę pracowników z „nowych” państw członkowskich (Duszczyk/Wiśniewski 2006, 8).

Dla porównania na rysunku 2 przedstawiona została emigracja Polaków do Wielkiej Brytanii na pobyt czasowy. W 2004 r. zdecydowanie więcej, bo 150 tys. osób,

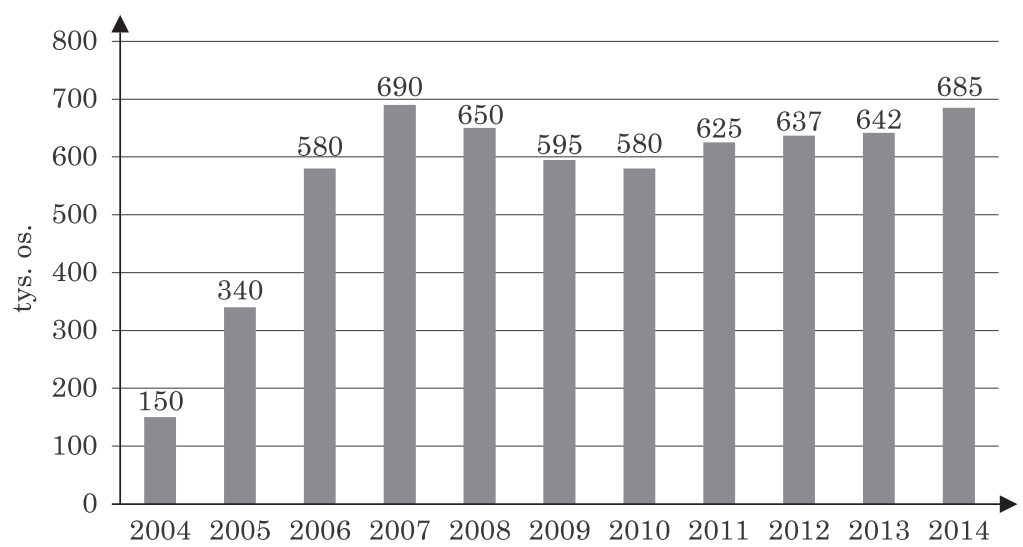

Rys. 2. Emigracja Polaków do Wielkiej Brytanii na pobyt czasowy w latach 2004-2014 Źródło: opracowanie własne na podstawie GUS, Informacja o rozmiarach i kierunkach emigracji z Polski w latach 2004-2016, Warszawa, 16.10.2017 
podjęło decyzję o wyjeździe na pewien czas za granicę. Również w 2006 r. najwięcej polskich emigrantów od momentu wejścia Polski do UE wyjechało za granicę (690 tys.). Liczba czasowych imigrantów na Wyspach rok później zmalała do 650 tys. i ta tendencja malejącej liczby imigrantów utrzymywała się aż do $2010 \mathrm{r}$. Natomiast od 2011 r. zauważalny jest ponowny wzrost emigracji do Zjednoczonego Królestwa, który utrzymywał się aż do $2014 \mathrm{r}$.

Powyższe dane liczbowe pokazują, jak olbrzymia jest skala migracji Polaków do Wielkiej Brytanii. Dane opublikowane przez brytyjski urząd statystyczny (ONS) dowodzą, że pod koniec 2014 r. w Wielkiej Brytanii mieszkało 853 tys. Polaków. Z tego względu Polacy są największą mniejszością narodową zamieszkującą Wyspy Brytyjskie $^{2}$. Zasoby siły roboczej wzbogacone o polskich pracowników sprawiły, że brytyjska gospodarka mogła się ciągle prężnie rozwijać, jednak dalszy i nieoczekiwany napływ zbyt wielu imigrantów w kolejnych latach okazał się sporym obciążeniem i problemem dla Wielkiej Brytanii.

\section{Migracja Polaków do Wielkiej Brytanii przed i po referendum w sprawie brexitu}

Referendum w sprawie brexitu, które zapoczątkowało proces wyjścia Wielkiej Brytanii z UE, spowodowało istotną zmianę uwarunkowań w migracji Polaków. Niepewność dotycząca dalszych losów polskich obywateli na Wyspach sprawia, że wielu z nich zastanawia się nad wyjazdem za granicę bądź powrotem do kraju.

Na rysunku 3 zaprezentowano dane na temat migracji Polaków na pobyt stały do Wielkiej Brytanii w latach 2014-2016. Zauważyć można, że znacząco zmalała liczba emigrujących osób - z 7392 osób w 2014 r., czyli przed referendum w sprawie brexitu, do 2946 osób w roku referendum. Natomiast, co ciekawe, Polacy, którzy wyemigrowali na stałe, zaczęli wracać do kraju, gdyż - jak pokazują liczby - skala zjawiska imigracji wzrosła o 342 osób Dla porównania w 2014 r. ogółem wyjechało na stałe 28,1 tys. mieszkańców Polski, natomiast wróciło z zagranicy 12,3 tys. osób. W 2016 r. sytuacja ta diametralnie się zmieniła, a mianowicie saldo migracji było dodatnie, co oznacza, że osób powracających z zagranicy było więcej niż opuszczających kraj. $\mathrm{Z}$ oficjalnych danych wynika, iż w tym czasie ogółem wyjechało 12 tys. mieszkańców Polski, a wróciło o 1,5 tys. osób więcej, czyli 13,5 tys. W 2017 r. tendencja ta utrzymywała się na podobnym poziomie, jednak saldo migracji było niższe o 0,1 p.p. i wynosiło $1,4^{3}$.

Spadek zainteresowania wyjazdami do Wielkiej Brytanii może być m.in. wynikiem poprawiających się warunków na polskim rynku pracy.

\footnotetext{
${ }^{2}$ Według danych Office of National Statistics (GB), https://www.ons.gov.uk [dostęp 7.09.2018].

${ }^{3}$ https://bdm.stat.gov.pl/ [dostęp 16.09.2018].
} 
Systematyczny wzrost popytu w gospodarce sprzyja rosnącemu zapotrzebowaniu na pracę, co przekłada się na dalszy wzrost zatrudnienia i obniżenie bezrobocia. W konsekwencji umacnia się pozycja pracowników w negocjacjach płacowych i rośnie udział firm prognozujących wzrost płac, co sprzyja przyśpieszeniu wzrostu wynagrodzeń (Raport o inflacji 2018).

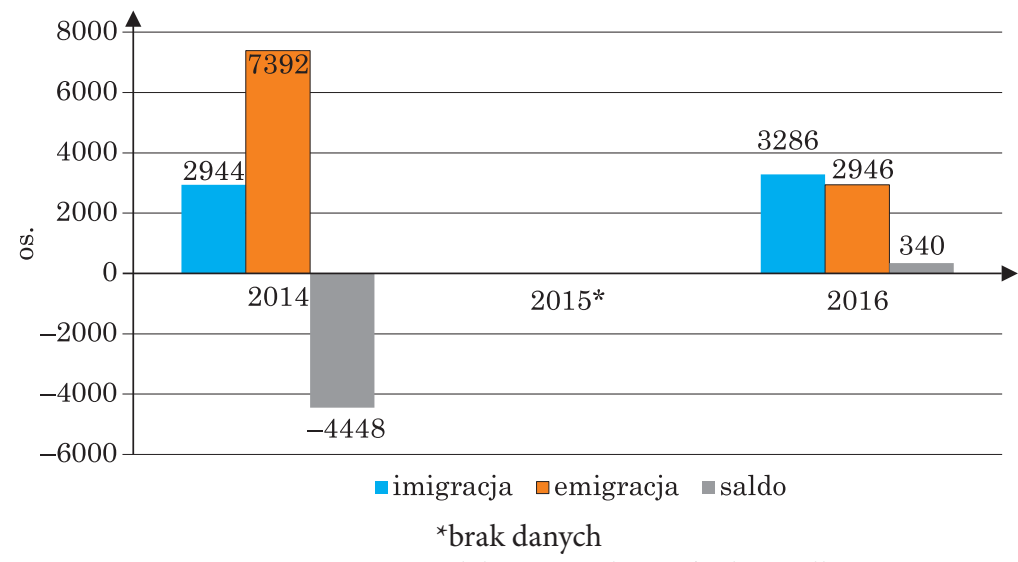

Rys. 3. Migracje zagraniczne Polaków na pobyt stały do Wielkiej Brytanii

Źródło: opracowanie własne na podstawie GUS, Rocznik demograficzny 2017, Warszawa, 13.10.2017

W przypadku emigracji Polaków na pobyt czasowy do Wielkiej Brytanii sytuacja wygląda nieco inaczej (rysunek 4). Po pierwsze zdecydowanie więcej Polaków zarówno przed referendum, jak i po nim decydowało się na czasową emigrację niż na pobyt stały. Pod koniec 2015 r. wyjechało 720 tys. osób, w porównaniu do $2014 \mathrm{r}$. było to o 35 tys. więcej. Z kolei pod koniec 2016 r., czyli po ogłoszeniu referendum,

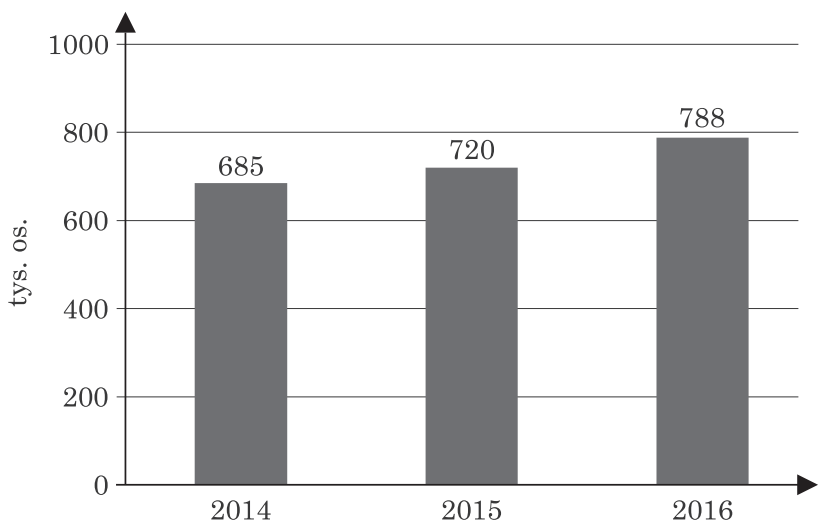

Rys. 4. Emigracja Polaków na pobyt czasowy do Wielkiej Brytanii Źródło: opracowanie własne na podstawie GUS, Rocznik demograficzny 2017, Warszawa, 13.10.2017 
wyemigrowało 788 tys. osób, czyli o 68 tys. więcej w stosunku do roku poprzedniego (w porównaniu do $2014 \mathrm{r}$. aż o 103 tys. więcej).

Oznacza to, że wielu polskich emigrantów decydowało się na wyjazd, żeby zdążyć przed brexitem. Polacy korzystali z ostatniej szansy na zarobienie pieniędzy, gdyż nikt tak naprawdę nie wiedział, jak będzie wyglądała sytuacja migracyjna po zakończonym procesie brexitu. Po referendum jednak można zauważyć wiele zmian na brytyjskim rynku pracy. Oficjalne dane ONS pokazują, że coraz więcej bezrobotnych Brytyjczyków podejmuje pracę. Stopa bezrobocia w pierwszym kwartale 2016 r., czyli jeszcze przed referendum, wynosiła 5,1\%, natomiast już w kolejnym kwartale była niższa o 0,2 p.p. Bezrobocie w tym kraju ciągle spada, a w 2017 r. było najniższe od 1974 r. i wynosiło 4,4\% ${ }^{4}$. Adekwatnie do sytuacji: jeżeli spada bezrobocie, to wzrasta zatrudnienie. W pierwszym kwartale $2018 \mathrm{r}$. wskaźnik zatrudnienia wynosił 75,6\% i był wyższy o 1,4 p.p. w porównaniu do pierwszego kwartału 2016 r. W związku z tym można powiedzieć, że poprawiła się sytuacja materialna wielu brytyjskich rodzin, które dotąd utrzymywały się z zasiłków socjalnych czy innych źródeł dochodu. Przeciętne tygodniowe wynagrodzenie ogółem, jak podaje ONS, w marcu 2016 r. wynosiło 491 E, rok później o $12 £$ więcej, a dwa lata po referendum wzrosło do $515 \mathfrak{£}^{5}$.

\section{Podsumowanie}

Rok 2004 to niewątpliwie okres przełomowy dla polskiej migracji do Wielkiej Brytanii. Swobodny przepływ ludności spowodował, że bez żadnych przeszkód Polacy mogli wyjechać za granicę. W 2006 r. na Wyspy Brytyjskie przybyło najwięcej migrantów zarobkowych od momentu przystąpienia Polski do UE. W kolejnych latach zainteresowanie wyjazdem za granicę na stałe nie było aż tak duże jak przed 2006 r. Zdecydowanie więcej mieszkańców Polski decydowało się na wyjazd czasowy niż na stałe. Kolejne tak duże zainteresowanie wyjazdem na stałe do Wielkiej Brytanii nastąpiło w 2013 r., jednak tendencja ta nie utrzymywała się zbyt długo.

Referendum w spawie brexitu, które odbyło się w 2016 r., spowodowało, że Polacy już tak chętnie nie chcieli wyjeżdżać na stałe do Zjednoczonego Królestwa, a wielu z tych, którzy wyjechali, postanowiło wrócić do Polski. Referendum nie miało dużego wpływu na migrację na pobyt czasowy, gdyż stosunkowo dużo obywateli Polski wyemigrowało w celach zarobkowych do Wielkiej Brytanii.

\footnotetext{
${ }^{4}$ https://www.ons.gov.uk/employmentandlabourmarket/peoplenotinwork/unemployment/timeseries/ mgsx/lms [dostęp 17.09.2018]

${ }^{5}$ Office of National Statistics (GB), https://www.ons.gov.uk [dostęp 17.09.2018].
} 


\section{Bibliografia}

BoroŃSKA-HrYNiEwIECKA, K. (2016), Wpływ Brexitu na sytuację imigrantów ekonomicznych w Wielkiej Brytanii: implikacje dla Polski i polskich obywateli. W: Biuletyn, Polski Instytut Spraw Międzynarodowych. 24, 1-2.

ByczeK, R. (2014), Emigracja Polaków do Wielkiej Brytanii i jej wpływ na rozwój turystyki przyjazdowej Brytyjczyków do Polski. W: Turystyka i Rekreacja. 14, 123-135.

DusZCZYK, M./WIŚNIEWSKI, J. (2006), Analiza społeczno-demograficzna migracji zarobkowej Polaków do państw EOG po 1 maja 2004 roku. Warszawa.

Finel, A. (2007), Najnowsza migracja z Polski do Wielkiej Brytanii. W: Biuletyn Migracyjny. 12, 1-6. GRABOWSKA-LuCiŃSKA, I./OKÓLSKI M., (2009), Emigracja ostatnia. Scholar, Warszawa.

KACZMARCZYK, T. (2015), Migracja - charakterystyka zjawiska. W: Zeszyty Naukowe Państwowej Szkoły Zawodowej im. Witelona w Legnicy. 16/3, 7-15.

KuCIŃsKI, K. (2004), Migracje w teorii ekonomii. International. W: Journal of Management and Economics. 15, 8-20.

Kundera, J. (2017), Brexit. Wrocław.

Nowotnik, D. (2011), Migracje zagraniczne w krajach Unii Europejskiej w warunkach kryzysu gospodarczego. W: Prace Komisji Geografii Przemysłu Polskiego Towarzystwa Geograficznego. $18,59-69$.

PikLikiewicz, M. (2000), Międzynarodowe stosunki gospodarcze na przełomie wieków. Warszawa. PodgóRZańska, R. (2016), Emigracja Polaków do Wielkiej Brytanii w latach 2004-2016. Implikacje dla stosunków polsko-brytyjskich. W: Przeszłość Demograficzna Polski. 3, 177-204.

Siek, E./BednarczyK, J. L. (2009), Kryzys ekonomiczny a migracje ludności Polski do wybranych krajów. W: Rocznik Żyrardowski. 7, 161-172 .

Tomaszewski, J. (2015), Wybrane aspekty polityki bezpieczeństwa Wielkiej Brytanii. W: Kwartalnik: Bezpieczeństwo Narodowe. 36, 25-40.

WoźNIAK, R. B. (1999) Socjologiczne implikacje migracji cudzoziemców w Polsce. Studium pogranicza polsko-niemieckiego. Szczecin.

\section{Źródła internetowe}

http://www.lexlege.pl/traktat-o-unii-europejskiej/art-50

https://bdm.stat.gov.pl

https://www.ons.gov.uk/peoplepopulationandcommunity/populationandmigration/internationalmigration/ datasets/populationoftheunitedkingdombycountryofbirthandnationality

https://www.ons.gov.uk/employmentandlabourmarket/peoplenotinwork/unemployment/timeseries/ $\mathrm{mgsx} / \mathrm{lms}$

https://www.ons.gov.uk/employmentandlabourmarket/peopleinwork/earningsandworkinghours/ timeseries/kab9/emp 
